Jurnal Adat dan Budaya, Vol.2, No.1 Tahun 2020

ISSN: E-ISSN 2615-6156, P-ISSN: 2615-6113

Jurnal Homepage: https://ejournal.undiksha.ac.id/index.php/JABI/index

\title{
Pengaruh Model Pembelajaran PAKEM Berbasis Tri Kaya Parisudha Terhadap Kompetensi Pengetahuan PPKN Siswa Kelas IV
}

\author{
Ni Putu Mira Ayunita Laksmi¹, I G. A. Agung Sri Asri², Md. Putra ${ }^{3}$ \\ 123 Jurusan Pendidikan Dasar, Universitas Pendidikan Ganesha, Singaraja, Indonesia \\ E-mail: mira.ayunita.laksmi@undiksha.ac.id
}

\begin{abstract}
Abstrak
Penelitian ini dilatarbelakangi oleh permasalahan pada kejenuhan siswa dalam belajar yang menyebabkan rendahnya kompetensi pengetahuan PPKn. Tujuan penelitian ini untuk mengetahui pengaruh yang signifikan model pembelajaran PAKEM berbasis Tri Kaya Parisudha terhadap kompetensi pengetahuan PPKn. Penelitian ini merupakan penelitian eksperimen semu dengan rancangan Nonequivalent Control Grup Design. Populasi penelitian ini meliputi seluruh siswa kelas IV sebanyak 289 siswa. Sampel penelitian ini ditentukan dengan teknik Cluster Random Sampling. Data kompetensi pengetahuan PPKn dalam penelitian ini dikumpulkan dengan menggunakan tes objektif dalam bentuk pilihan ganda biasa. Setelah itu data dianalisis menggunakan uji-t. Hasil analisis data diperoleh $t_{\text {hitung }}=3,048$ dengan $\mathrm{dk}=70$ dan taraf signifikansi $5 \%$ maka diperoleh $t_{\text {tabel }}=2,000$. Karena thitung 3,048 $>$ tabel $=2,000$ maka $\mathrm{H}_{\mathrm{o}}$ ditolak dan $\mathrm{H}_{\mathrm{a}}$ diterima. Hal ini berarti terdapat perbedaan yang signifikan kompetensi pengetahuan PPKn siswa yang dibelajarkan menggunakan model pembelajaran PAKEM berbasis Tri Kaya Parisudha dan siswa yang dibelajarkan menggunakan pembelajaran konvensional pada siswa kelas IV. Implikasi teoretis dalam penelitian ini membuktikan model pembelajaran PAKEM berbasis Tri Kaya Parisudha dapat diterapkan dengan baik dalam pembelajaran untuk mengoptimalkan kompetensi pengetahuan PPKn siswa. Nilai rata-rata kompetensi pengetahuan PPKn kelompok eksperimen adalah $\bar{X}=85,094$ sedangkan nilai rata-rata kompetensi pengetahuan PPKn kelompok kontrol adalah $\bar{X}=74,782$. Jadi nilai rata-rata kompetensi pengetahuan PPKn kelompok eksperimen lebih tinggi daripada nilai rata-rata kompetensi pengetahuan PPKn kelompok kontrol yaitu 85,094 > 74,782. Dengan demikian dapat disimpulkan bahwa terdapat pengaruh yang signifikan model pembelajaran PAKEM berbasis Tri Kaya Parisudha terhadap kompetensi pengetahuan PPKn siswa kelas IV SDN Gugus Patimura Denpasar Selatan Tahun Ajaran 2019/2020.
\end{abstract}

Kata Kunci: PAKEM; Tri Kaya Parisudha; PPKn

\begin{abstract}
This research in background by problem on saturation student in learning that cause of lows civics knowledge competence. The aim this research to know there is significant influence of PAKEM learning model base on Tri Kaya Parisudha aginst civics knowledge competence. This research is quasi experimental research with nonequivalent control group design. This research population includes all grade IV students as many 289 students. This Research of sample determined with Cluster Random Sampling technique. Knowledge competency data civics collected using objective test in form of multiple choice. Data were analyzed using t-test. The result of data analysis obtainable $t_{\text {count }}=3,048$ with $\mathrm{dk}=70$ and significance level $5 \%$ that obtainable table $=2,000$ because $t_{\text {count }}=3,048$ $>t_{\text {table }}=2,000$ that $\mathrm{H}_{\mathrm{o}}$ rejected and $\mathrm{H}_{\mathrm{a}}$ received. This means there is significant difference of civics knowledge competence students that learned use PAKEM learning model base on Tri Kaya Parisudha and students that learned use conventional learning of grade IV students. Theoretical implications in this study prove that PAKEM learning model based on Tri Kaya Parisudha can be applied well in learning to optimize competency of students Civis knowledge. Average value civics knowledge competence of experimental group is $\bar{X}=85,094$ while average value civics knowledge competence of control group is $\overline{\mathrm{X}}=74,782$. So that average value civics knowledge competence of experimental group were higher than average value civics knowledge competence of control group that is 85,094 $>74,782$. Thus it can be concluded there is significant influence of PAKEM learning model base on Tri Kaya Parisudha aginst civics knowledge competence of grade IV students SDN Gugus Patimura South Denpasar Academic Year 2019/2020.
\end{abstract}

Keywords: PAKEM; Tri Kaya Parisudha; Civics 


\section{PENDAHULUAN}

Pendidikan adalah usaha untuk membentuk manusia yang utuh secara lahir dan batin, cerdas, sehat, dan memiliki berbudi pekerti yang luhur. Pendidikan mampu membentuk kepribadian siswa yang matang secara lahir dan batin menyangkut akhlak mulia, cakap, kreatif, mandiri, dan bertanggung jawab. Dalam pembangunan dan peningkatan Sumber Daya Manusia (SDM) berhubungan dengan salah satu bagian penting dari suatu pendidikan.

Menuju pendidikan kearah yang lebih baik dapat membentuk suatu sumber daya manusia yang baik pula. Pendidikan sebagai dorongan untuk megembangkan dan membangun potensi yang ada pada diri siswa sesuai dengan kualitas dan standar yang ada dalam masyarakat (Anwar, 2015). Manusia yang berkualitas itu, dilihat dari segi pendidikan yang telah terkandung secara jelas dalam tujuan pendidikan nasional. Untuk itu dilakukannya berbagai macam cara dalam meningkatkan sumber daya manusia yang berkualitas seperti peningkatan kurikulum yang disesuaikan dengan arus perkembangan jaman. Seperangkat rencana dan pengaturan mengenai tujuan, isi, dan bahan pelajaran serta cara yang digunakan sebagai pedoman penyelengaraan kegiatan pembelajaran untuk mencapai tujuan pendidikan tertentu yang merupakan pengertian dari kurikulum yang tercantum dalam UU No. 20 Tahun 2003 Tentang Sistem Pendidikan Nasional. Kurikulum merupakan alat yang sangat penting digunakan bagi keberhasilan suatu pendidikan (Kurniasih \& Sani, 2014). Tujuan pendidikan nasional diselenggarakan untuk memahami perkembangan kurikulum dengan mempertimbangkan tahap peningkatan perkembangan siswa dan kesesuaiannya dengan lingkungan, kemajuan ilmu pengetahuan dan teknologi.

Kurikulum 2013 dirancang untuk memberikan pengalaman belajar seluas - luasnya bagi siswa dalam mengembangkan pengetahuan yang dimiliki. Seorang guru selain memiliki pengetahuan yang luas juga harus memiliki kemampuan dalam proses pembelajaran terutama memiliki kemampuan dalam penyampaian pelajaran atau materi agar para siswa tidak merasa bosan dalam proses pembelajaran yang berlangsung, sesuai dengan Kurikulum 2013 yang pola pembelajarannya berpusat kepada siswa. Pembelajaran di Sekolah Dasar dilaksanakan melalui pembelajaran tematik terpadu, yaitu pembelajaran yang terdiri dari tema - tema yang diintegrasikan kedalam beberapa pelajaran yang saling berkaitan.

Pembelajaran tematik dengan muatan materi PPKn bertujuan untuk membantu siswa dapat belajar dengan baik dan membentuk karakter siswa yang seutuhnya. Pembelajaran PPKn adalah Pendidikan Pancasila yang terdapat komponen untuk membangun semangat dan nilai-nilai 1945 kepada generasi muda (Darmadi, 2014). Dengan demikian dapat disimpulkan bahwa kompetensi pengetahuan PPKn adalah kemampuan siswa yang mencangkup proses mengingat, memahami, menerapkan, menganalisis, mengevaluasi, dan mencipta untuk membangun watak, karakter sebagai warga negara yang demokratis, dan memiliki pilihan untuk memahami dan mengaktualisasikan hakhak dan kewajiban untuk menjadi warga negara Indonesia yang berwawasan luas, terampil dan merefleksikan dirinya dalam merencanakan kehidupan berdasarkan pancasila dan UUD 1945 yang diperoleh siswa dengan pengalaman langsung. PPKn penting diberikan sejak dini untuk mempersiapkan siswa menjadi insan yang berkarakter, berperilaku baik, cerdas dan terampil sesuai dengan pembelajaran abad ke-21 yang merupakan suatu pembelajaran mengubah pendekatan pembelajaran dari berpusat pada pendidik menjadi berpusat pada siswa. Hal ini sesuai dengan tuntutan masa depan yang menjadi siswa memiliki kecakapan berpikir dan belajar, serta mempunyai karakter yang diharapkan seperti religius, nasionalis, mandiri, gotong royong, dan integritas. Siswa diharapkan mampu berperan secara aktif dalam proses mencari, mengolah, mengkonstruksi, dan menerapkan pengetahuan dari pembelajaran maupun pengalaman yang telah diperolehnya sehingga pembelajaran menjadi lebih bermakna.

Pada kenyataan yang ada di lapangan masih banyak guru yang belum secara optimal menerapkan variasi model pembelajaran sehingga siswa masih mengalami kejenuhan dalam kegiatan pembelajaran. (Rusman, 2016) menjelaskan bahwa variasi pembelajaran harus mampu mengaktifkan siswa yang menyebabkan terjadinya suatu perubahan pada diri siswa dalam proses pembelajaran, sehingga kegiatan pembelajaran harus dirancang dengan baik agar mencapai hasil yang optimal. Dalam pemilihan variasi pembelajaran seorang guru dapat menyesuaikan kegiatan yang digunakan dan efiesien untuk mencapai tujuan pendidikannya. (Krisnawati et al., 2013) dalam penelitian yang dilakukan terdapat kendala dalam menciptakan suasana belajar yang menarik oleh sebab itu guru harus mendapatkan perhatian agar siswa senang belajar menggunakan pembelajaran yang bervarisasi. Sejalan dengan penelitian 
(Ginting, 2017) bahwa proses pembelajaran harus menciptakan suasana pembelajaran sehingga siswa aktif bertanya, mengemukakan pendapat, kreatif serta berkonsentrasi secara penuh dalam pembelajaran. Kegiatan pembelajaran yang diberikan mampu menggali daya kreativitas setiap siswa dalam menemukan suatu ide-ide atau gagasan baru sehingga tidak sama dengan yang telah ada. Apabila siswa tidak diberikan kesempatan dalam pembelajaran untuk berperan secara aktif maka pembelajaran akan bertentangan dengan hakikat belajar (Sulastri, 2019). Oleh sebab itu masih perlu dikembangkan berbagai macam variasi pembelajaran pada kegiatan pembelajaran yang diberikan guru. Dengan demikian terdapat kesenjangan antara kenyataan yang ada di lapangan dengan tujuan Kurikulum 2013.

Pada proses pembelajaran yang diberikan oleh guru di sekolah pembelajaran hanya berdasarkan buku pegangan siswa sehingga kurang menarik perhatian siswa yang menyebabkan kejenuhan yang ada dalam diri siswa ketika belajar sehingga hasil pembelajaran kurang optimal. Hal ini diperkuat dari informasi yang diperoleh saat melakukan observasi serta wawancara yang dilakukan pada kelas IV SDN Gugus Patimura. Dari informasi yang diperoleh diketahui bahwa masalah yang ditemukan yang menyebabkan rendahnya kompetensi pengetahuan PPKn siswa ialah masih kurangnya partisipasi siswa dalam proses pembelajaran, timbulnya interaksi siswa yang mengarah pada hal yang menggangu kegiatan pembelajaran, penggunaan variasi model pembelajaran yang belum diterapkan secara optimal sehingga terjadinya kejenuhan dalam diri siswa yang dapat mempengaruhi kompetensi pengetahuan siswa.

Upaya untuk meningkatkan mutu pendidikan utamanya peningkatan kompetensi pengetahuan harus didukung dari segi kualitas guru, model pembelajaran maupun sarana dan prasarana pembelajaran. Penggunaan model pembelajaran selama kegiatan pembelajaran dapat dianggap sebagai metode yang tepat untuk menyelesaikan suatu kegiatan pembelajaran. Saat ini pembelajaran konvensional yang banyak digunakan dalam proses pembelajaran kurang menarik perhatian bagi siswa sehingga kurang optimalnya penguasaan materi bagi siswa, serta timbulnya interaksi antar siswa dalam kegiatan pembelajaran yang masih mengarah ke dalam hal yang mengganggu pembelajaran.

Berdasarkan permasalahan tersebut, pencapaian kompetensi pengetahuan perlu didukung dengan proses pembelajaran yang bervariasi. Variasi dalam pembelajaran bahwa seorang guru dapat melakukan pemanfaatan metode, pendekatan, model dan strategi dengan tujuan bahwa apa yang ditemukan oleh siswa dapat dipahami dengan benar. Pemberian kegiatan di kelas perlu dirancang secara kreatif dan menyenangkan dengan memperhatikan karakteristik perkembangan siswa kelas IV sekolah dasar.

Kegiatan pembelajaran yang dilakukan secara menyenangkan menimbulkan proses belajar yang efektif sehingga mendorong siswa lebih termotivasi untuk terus belajar sendiri tanpa diperintah dan tidak merasa terbebani. Oleh sebab itu perlu diterapkan alternatif pembelajaran yang bisa menjadi solusi pemecahan masalah tersebut yang dipandang perlu adanya variasi suatu pembelajaran. Salah satunya dengan melakukan suatu variasi yang dimaksud ialah menerapkan model pembelajaran PAKEM (Pembelajaran Aktif, Kreatif, Efektif dan Menyenangkan). Sejalan dengan penelitian yang dilakukan oleh (Ary W et al., 2014) menjelaskan bahwa Pembelajaran PAKEM mendorong siswa untuk lebih aktif, mau mengembangkan kreatifitas di dalam dirinya serta tidak merasa takut untuk mengemukakan pendapat di dalam kelas. (Rusman, 2016) menjelaskan bahwa PAKEM merupakan model pembelajaran serta digunakan sebagai panduan dalam bertindak untuk mencapai tujuan pembelajaran yang direncanakan. Pembelajaran yang baik dan menyenangkan bagi siswa sangat penting dalam pembelajaran model PAKEM. Diperlukannya rancangan skenario pembelajaran yang mengena dan tetap menyenangkan, pembelajaran berpusat pada siswa, maka siswa menjadi lebih mendominasi pembelajaran serta terlibat aktif pembelajaran (Sulastri, 2019). Dalam penelitian yang dilakukan oleh (Rithayanti et al., 2014) menjelaskan bahwa siswa dapat membangun sebuah konsep dari pengalaman yang pernah dialami dalam lingkungan sehari-hari sehingga pembelajaran lebih bermakna yakni menggunakan pembelajaran PAKEM. Serta penelitian yang dilakukan oleh (Suparman, 2016) dalam pembelajaran PAKEM dapat meningkatkan kualitas pembelajaran PKn dan memiliki dampak positif dalam meningkatkan prestasi belajar siswa. Dengan penggunaan pembelajaran PAKEM, diharapkan berkembangnya berbagai jenis inovasi kegiatan pembelajaran dibuat untuk mencapai tujuan pembelajaran yang menghasilkan pembelajaran yang partisipatif, aktif, efektif dan menyenangkan. Dapat disimpulkan bahwa model PAKEM adalah suatu model pembelajaran yang mempunyai pedoman dalam bertindak serta menekankan pada pembelajaran yang menyenangkan untuk mencapai suatu tujuan pembelajaran yang menjadikan siswa lebih aktif, dan kreatif. 
Iru \& Arihi (2012) menjelaskan kelebihan model pembelajaran PAKEM, yaitu (1) PAKEM merupakan pembelajaran yang mengembangakan kecakapan hidup, (2) Dalam PAKEM siswa belajar bekerja sama, (3) PAKEM mendorong siswa menghasilkan karya kreatif, (4) PAKEM mendorong siswa untuk terus maju mencapai sukses, (5) PAKEM menghargai potensi semua siswa, (6) Program untuk meningkatkan PAKEM di sekolah harus ditingkatkan kuantitas dan kualitasnya. Berdasarkan kelebihan tersebut, secara teoritis model pembelajaran PAKEM mampu membuat siswa lebih aktif dalam mengikuti pembelajaran dan memahami konsep pengetahuan PPKn sehingga tercipta suasana pembelajaran yang aktif serta menjadikan suatu pembelajaran menjadi lebih menyenangkan.

Dalam PAKEM ada empat pilar utama, yaitu: (1) Aktif, (2) Kreatif, (3) Efektif, dan (4) Menyenangkan, dan huruf $P$ merupakan pembelajaran yang didefinisikan sebagai pengorganisasian atau mengarahkan situasi lingkungan yang baik yang memungkinkan terjadinya keinginan belajar pada siswa. Dengan demikian ketika siswa belajar, pilar - pilar PAKEM yang menyertainya harus direncanakan menurut (Indrawati \& Wanwan 2009) sebagai berikut: pembelajaran aktif yang berpusat pada siswa mengajak untuk berpikir dan berbuat, pembelajaran kreatif ialah pembelajaran yang mengajak siswa untuk berpikir secara kritis, mempunyai pikiran yang terbuka, pembelajaran efektif ialah pembelajaran yang menghasilkan apa yang harus dikuasai siswa, dan pembelajaran menyenangkan yaitu pembelajaran yang mengajak siswa untuk menyukai kegiatan belajar, menciptakan suasana belajar yang nyaman dan aman sehingga keadaan kelas menjadi bersemangat dan terdapat interaksi dalam pembelajaran.

Siswa dapat diberikan kesempatan untuk berpartisipasi aktif didalam proses pembelajaran, mendorong siswa untuk bereksplorasi guna mendapatkan proses pembelajaran yang menyenangkan untuk menghasilkan siswa yang aktif, kreatif, serta unggul dalam bidangnya masing - masing. Untuk mengoptimalkan kompetensi pengetahuan PPKn siswa, maka diperlukan suatu inovasi dalam pembelajaran yang dapat mengaitkan materi pelajaran dengan pelajaran hidup di masyarakat sehingga pembelajaran dengan muatan materi PPKn lebih bermakna yaitu dengan menerapkan model pembelajaran PAKEM berbasis Tri Kaya Parisudha. (Widiasih et al., 2019) menjaskan bahwa Tri Kaya Parisudha merupakan suatu ajaran yang menjadi tuntunan bagi umat hindu yaitu tuntunan dalam berkata, berpikir dan berbuat. Sehingga pembelajaran yang menggunakan Tri Kaya Parisudha memberikan dampak yang baik bagi perkembangan siswa.

Tri Kaya Parisudha diartikan sebagai berpikir baik, berkata baik, dan berbuat baik. Jadi pikiran, perkataan, dan perbuatan tersebut haruslah dilakukan secara baik. Dengan pikiran yang baik akan memunculkan suatu perkataan yang baik, jadi semua dipengaruhi oleh pikiran karena itulah maka orang harus menjaga gerakan dan ketenangan pikirannya dengan begitu pikiran akan menjadi terkendali, tentram dan tenang sehingga terdorong suatu perbuatan yang baik dan benar. Sesuai dengan penelitian yang dilakukan (Sariani et al., 2018) menjelaskan bahwa Tri Kaya Parisudha akan membantu proses menanamkan nilai-nilai moral dan norma pada siswa, serta (Dewi et al., 2014) menjelaskan mengenai Tri Kaya Parisudha merupakan pembelajaran tentang dasar cara berperilaku yang baik, dari adanya pikiran yang baik, maka akan menimbulkan perkataan yang baik, dan pada akhirnya akan mengarah pada perbuatan yang baik pula.

Melalui penerapan model pembelajaran PAKEM yang berbasis Tri Kaya Parisudha ini diharapkan mampu meningkatkan kompetensi pengetahuan secara mandiri maupun dalam melakukan tugas yang diberikan oleh guru terutama dalam pembelajaran PPKn dan bidang pelajaran lainnya, maka siswa dapat mengembangkan pemahaman dan kemampuan yang dimiliki oleh siswa dengan penekanan pada belajar melalui berpikir, berkata, dan berbuat. Model pembelajaran PAKEM berbasis Tri Kaya Parisudha akan membuat pembelajaran lebih bermakna, siswa akan mengaitkan ajaran - ajaran agama dengan kegiatan pembelajaran yang menyenangkan. Menerapkan model PAKEM dapat meningkatkan karakter siswa dalam mengikuti kegiatan belajar. Pembelajaran dengan muatan materi PPKn di SD bertujuan untuk meningkatkan konsep pemahaman siswa, menuntut siswa untuk dapat terlibat secara aktif melalui kegiatan belajar.

Model pembelajaran PAKEM diselipkan salah satu ajaran kearifan lokal masyarakat Bali agar menunjang tercapainya tujuan pembelajaran PPKn. Salah satu kearifan lokal yang terkait dengan kompetensi pengetahuan siswa dan diselipkan dalam model pembelajaran PAKEM yaitu Tri Kaya Parisudha. Ajaran Tri Kaya Parisudha sebagai tuntunan bagi manusia dalam melaksanakan kehidupan hendaknya berperilaku yang baik yaitu dengan cara berpikir yang baik (manacika), berkata yang baik (wacika), dan berbuat yang baik (kayika) (Suhardana, 2007). Tri Kaya Parisudha sebagai pedoman hidup 
masyarakat Bali dalam proses pembelajaran berbasis Tri Kaya Parisudha ini dapat menjadi dasar untuk mendorong, membimbing, dan mengarahkan siswa untuk berperilaku yang baik sesuai dengan perkembangannya.

Muatan materi PPKn yang berorientasi pada Tri Kaya Parisudha berarti pembelajaran PPKn berupaya memfasilitasi siswa untuk selalu dapat berpikir yang baik, berkata yang baik dan berbuat yang baik. Siswa akan saling bekerja sama untuk membantu dalam kelompok untuk mencapai suatu tujuan. Dalam pelaksanaan pembelajaran ini sangat memperhatikan tiga tahapan manusia dalam berperilaku yaitu berpikir, berkata, dan berbuat yang baik. Dalam pembelajaran dilandasi dengan bagian Tri Kaya Parisudha yaitu manacika, wacika, dan kayika sehingga semua aktivitas siswa akan terarah pada hal hal yang positif.

Berdasarkan hasil penelitian yang dilakukan oleh Pradnyawathi \& Agustika (2019) yang berjudul Pengaruh Model PAKEM Berbasis Tri Hita Karana Terhadap Keterampilan Menulis menyatakan bahwa adanya pengaruh dalam penggunaan model pembelajaran PAKEM dan hasil penelitian oleh (Indrayani et al., 2018) yang berjudul Pengaruh Model Pembelajaran Kooperatif Tipe TTW Berbasis Tri Kaya Parisudha Terhadap Hasil Belajar IPA Pada Siswa Kelas V SD, menyatakan bahwa terdapat perbedaan yang signifikan antara hasil belajar kelompok siswa yang belajar dengan menggunakan model pembelajaran kooperatif tipe Think Talk Write (TTW) berbasis Tri Kaya Parisudha dan kelompok siswa yang belajar menggunakan model pembelajaran konvensional pada mata pelajaran IPA siswa kelas V SD. Penelitian yang dilakukan oleh(Nurhayati, 2016) menjelaskan bahwa penerapan Model Pembelajaran Aktif, Kreatif, Efektif dan Menyenangkan (PAKEM) juga dapat meningkatkan nilai rata-rata prestasi belajar PKn. Dan (Ernawati, 2018) penerapan ajaran Tri Kaya Parisudha sudah diterapkan maksimal tentunya namun masih perlu peningkatan dikarenakan berbagai hambatan diantaranya faktor internal dan eksternal dari sekolah dan dari lingkungan rumah, agar kedepannya bisa menghasilkan peserta didik yang berakhlak mulia seperti yang di harapkan bersama

Oleh sebab itu, peneliti memiliki ketertarikan dalam melakukan penelitian terhadap model pembelajaran PAKEM berbasis Tri Kaya Parisudha terhadap kompetensi pengetahuan PPKn. Berdasarkan uraian diatas, tujuan penelitian ini adalah sebagai berikut untuk mengetahui Pengaruh Model Pembelajaran PAKEM berbasis Tri Kaya Parisudha terhadap Kompetensi Pengetahuan PPKn Siswa Kelas IV SDN Gugus Patimura Denpasar Selatan Tahun Ajaran 2019/2020.

Sesuai dengan uraian tersebut, secara teoritis penerapan model pembelajaran PAKEM berbasis Tri Kaya Parisudha terhadap kompetensi pengetahuan siswa yang pada penelitian yang dilakukan lebih menfokuskan kompetensi pengetahuan PPKn, tetapi secara empiris perlu dibuktikan melalui penelitian yang berjudul "Pengaruh Model Pembelajaran PAKEM Berbasis Tri Kaya Parisudha Terhadap Kompetensi Pengetahuan PPKn Siswa Kelas IV SDN Gugus Patimura Denpasar Selatan Tahun Ajaran 2019/2020".

\section{METODE}

Penelitian ini dilaksanakan di SDN Gugus Patimura Denpasar Selatan. Sekolah yang dijadikan sebagai tempat penelitian kelompok eksperimen dan kelompok kontrol yaitu SD Negeri 7 Sesetan pada kelas IV sebagai kelompok kontrol dan SD Negeri 11 Sesetan pada kelas IV A sebagai kelompok eksperimen. Penelitian ini dilaksanakan pada semester genap tahun ajaran 2019/2020 di kelas IV SDN Gugus Patimura Denpasar Selatan. Penelitian ini menggunakan penelitian eksperimen dengan desain eksperimental yaitu quasi experiment design (eksperimen semu). Tujuan dari penelitian ini adalah untuk mengetahui pengaruh yang signifikan model pembelajaran PAKEM berbasis Tri Kaya Parisudha terhadap kompetensi pengetahuan PPKn siswa kelas IV SDN Gugus Patimura Denpasar Selatan. Desain Eksperimen semu yang digunakan dalam penelitian ini adalah Nonequivalent Control Group Design. Dalam rancangan penelitian non-equivalent control group design, ada dua kelompok subjek, satu kelompok mendapat perlakuan dan satu kelompok lagi sebagai kelompok kontrol. Sebelum pemberian perlakuan, dilakukan pengukuran awal atau pre-test terhadap kedua kelompok tersebut. Selanjutnya, pada kelompok eksperimen diberikan perlakuan $(\mathrm{X})$ yaitu, model pmbelajaran PAKEM berbasis Tri Kaya Parisudha, sedangkan untuk kelas kontrol menggunakan pembelajaran konvensional. Setelah itu, kedua kelompok dilakukan pengukuran pasca pemberian perlakuan atau pasca tes. Prosedur Penelitian yang dilaksanakan pada penelitian ini terdiri dari tiga tahapan, yaitu tahap persiapan, tahap pelaksanaan, dan tahap akhir. 
Populasi merupakan seluruh kumpulan objek maupun orang - orang yang mempunyai karakteristik tertentu yang menjadi perhatian dalam suatu penelitian dan ditarik kesimpulannya. Populasi dalam penelitian ini adalah seluruh siswa kelas IV SDN Gugus Patimura Denpasar Selatan Tahun Ajaran 2019/2020 sebanyak 289 terdiri dari 8 kelas dari 5 SD Negeri yang ada di Gugus Patimura Denpasar Selatan. Terdapat 5 SD Negeri di Gugus Patimura Denpasar Selatan yaitu SD Negeri 1 Sesetan, SD Negeri 3 Sesetan, SD Negeri 7 Sesetan, SD Negeri 11 Sesetan, SD Negeri 18 Sesetan. Dari populasi yang telah ditentukan maka selanjutnya diambil perwakilan dari populasi tersebut yang dianggap mewakili seluruh populasi. Sampel merupakan bagian dari populasi untuk dijadikan sebagai objek penelitian. Berdasarkan populasi siswa kelas IV SDN Gugus Patimura yang terdiri dari 8 kelas dipilih 2 kelas sebagai sampel penelitian, yaitu kelas eksperimen dan kelas kontrol. Untuk menentukan kelas eksperimen dan kelas kontrol maka teknik yang digunakan untuk pengambilan sampel dalam penelitian ini ialah menggunakan Cluster Random Sampling. Cluster Random Sampling adalah pengambilan sampel dari unit - unit rumpun atau kelompok yang telah ditentukan atau tersedia (Setyosari, 2015). Teknik Cluster Random Sampling adalah cara yang digunakan dalam penentuan sampel apabila obyek yang akan diteliti atau sumber data sangat luas (Sugiyono, 2017b). Dari kedua pendapat maka dapat disimpulkan bahwa Cluster Random Sampling merupakan teknik sampling yang digunakan untuk menentukan sampel dalam suatu unit - unit rumpun atau kelompok dan semua anggota kelompok tersebut harus dimasukkan dalam sampel. Untuk menentukan sampel mana yang dijadikan sumber data, maka pengambilan sampelnya berdasarkan kelompok populasi yang telah ada sebelumnya. Penelitian ini tidak melakukan pengacakan terhadap obyek penelitian (siswa) melainkan yang diacak adalah kelompok kelas yang sebelumnya telah dibentuk tanpa dicampuri oleh kepentingan penelitian. Hal ini untuk menghindari kemungkinan siswa menyadari dirinya terlibat dalam eksperimen, maka penelitian ini dapat menggambarkan keadaan sesungguhnya dengan pengaruh perlakuan yang diberikan.

Penentuan sampel dalam penelitian ini dilakukan dengan cara pengundian, sehingga semua anggota populasi memiliki kesempatan yang sama untuk menjadi sampel penelitian. Cara undian yang dilakukan dengan menuliskan semua nama kelas IV diseluruh SDN Gugus Patimura. Populasi yang berjumlah 8 kelas pada masing - masing kertas, kemudian digulung dan dimasukkan ke dalam wadah dan dikocok untuk memilih dua kelas yang dijadikan sampel penelitian. Dari kedua kelas yang keluar kemudian diundi kembali untuk menentukan kelompok eksperimen dan kelompok kontrol. Setelah kedua kelas terpilih melalui cara pengundian dilakukan uji kesetaraan sampel dengan diberikan prates, nilai dari hasil prates yang dilakukan tersebut untuk mengetahui tingkat kesetaraannya menggunakan uji t bentuk polled varians. Melalui proses pengundian tersebut, diperoleh kelas IV SD Negeri 7 Sesetan sebagai kelompok kontrol dan kelas IV A SD Negeri 11 Sesetan sebagai kelompok eksperimen.

Data merupakan hal yang sangat penting dalam sebuah penelitian. Metode yang digunakan dalam penelitian ialah dengan metode tes. Setyosari (2015:231) menyatakan "dalam kegiatan pengumpulan data peneliti dapat menggunakan tes untuk mengukur kemampuan atau kompetensi". Pada prinsipnya meneliti adalah melakukan pengukuran, maka harus ada alat yang diukur. Instrumen penelitian merupakan suatu alat ukur yang digunakan dalam suatu penelitian (Sugiyono, 2017a). Instrumen yang digunakan adalah untuk mengumpulkan data kompetensi pengetahuan PPKn adalah tes. Tes adalah alat atau prosesdur yang digunakan untuk mengetahui atau mengukur sesuatu dalam suasana, dengan cara dan aturan yang ditetapkan (Arikunto, 2016). Tes yang digunakan untuk mengukur penguasaan kompetensi pengetahuan PPKn dalam penelitian ini berupa tes objektif dalam bentuk pilihan ganda biasa. Setiap item diberikan skor 1 apabila siswa menjawab dengan benar, disesuaikan dengan kunci jawaban, dan skor 0 apabila siswa menjawab salah. Skor pada setiap jawaban dijumlahkan dan dinilai yang kemudian menjadi nilai kompetensi pengetahuan PPKn siswa. Sebelum memberikan tes kepada siswa terlebih dahulu menguji kelayakan instrumen tes yang digunakan untuk mengukur tingkat pemahaman konsep PPKn. Instrumen yang digunakan dalam penelitian ini diuji coba melalui uji validitas, daya beda, indeks kesukaran dan uji reliabilitas.

Dalam penelitian ini, melibatkan dua variable, yaitu variabel terikat dan variabel bebas. Variabel bebas dalam penelitian adalah model pembelajaran PAKEM Berbasis Tri Kaya Parisudha yang diterapkan pada kelompok eksperimen dan pembelajaran konvensional yang diterapkan pada kelompok kontrol. Variabel terikat dalam penelitian ini adalah kompetensi pengetahuan PPKn siswa kelas IV SDN Gugus Patimura Denpasar Selatan. Pada penelitian ini variabel yang digunakan adalah kompetensi pengetahuan PPKn. Pencapaian siswa dalam aspek pengetahuan meliputi enam penguasaan yaitu mengingat, memahami, menerapkan, menganalisis, mengevaluasi, dan mencipta, diukut 
menggunakan tes sehingga memperoleh skor kompetensi pengetahuan setelah mengalami proses belajar. Kelompok eksperimen diberikan perlakuan pembelajaran dengan model pembelajaran PAKEM berbasis Tri Kaya Parisudha dan kelompok kontrol tidak diberikan perlakuan melainkan menggunakan pembelajaran konvensional. Sebelum dilakukan pemberian perlakuan, kelompok eksperimen dan kelompok kontrol diberikan pre-test untuk mengetahui kemampuan awal siswa. Jika data pre-test yang diperoleh sudah memenuhi uji prasyarat analisis, yaitu dengan uji normalitas sebaran data dan uji homogenitas varians maka dianalisis kesetaraan siswa menggunakan uji t. Pada penelitian ini variabel yang digunakan adalah kompetensi pengetahuan PPKn. Pencapaian siswa dalam aspek pengetahuan meliputi enam penguasaan yaitu mengingat, memahami, menerapkan, menganalisis, mengevaluasi, dan mencipta, diukut menggunakan tes sehingga memperoleh skor kompetensi pengetahuan setelah mengalami proses belajar.

Setelah data dalam penelitian ini terkumpul maka selanjutnya dilakukan analisis data. Teknik analisis data yang digunakan untuk menganalisis data dalam penelitian ini adalah teknik statistik inferensial. Dalam penelitian ini teknik analisis yang digunakan untuk menguji hipotesis menggunakan uji-t. Sebelum dilakukan uji-t, terlebih dahulu harus memenuhi uji prasyarat analisis, yaitu dengan uji normalitas sebaran data dan uji homogenitas varians. Uji homogenitas sebaran data dilakukan untuk mengetahui apakah sebaran data kompetensi pengetahuan PPKn siswa masing - masing kelompok berdistribusi normal atau tidak, sehingga dapat menentukan teknik analisis data. Uji normalitas sebaran data pada penelitian ini menggunakan uji Kolmogorov-Smirnov. Uji homogenitas dilakukan dengan tujuan untuk menunjukkan bahwa perbedaan yang terjadi pada uji hipotesis benar - benar terjadi akibat adanya perbedaan antar kelompok. Uji homogenitas varians dilakukan dengan uji Fisher (Uji F).

\section{HASIL DAN PEMBAHASAN}

Berdasarkan penelitian yang telah dilaksanakan pada kelompok eksperimen diketahui bahwa pemberian perlakuan menggunakan model pembelajaran PAKEM berbasis Tri Kaya Parisudha yang dilakukan sebanyak 6 kali pada siswa SD Negeri 11 Sesetan yang berjumlah 34 orang siswa dan pada kelompok kontrol pemberian perlakuan menggunakan pembelajaran kovensional sebanyak 6 kali pada siswa SD Negeri 7 Sesetan yang berjumlah 38 orang siswa. Pada akhir penelitian siswa diberikan posttest untuk memperoleh data kompetensi pengetahuan PPKn siswa. Kompetensi pengetahuan PPKn pada kelompok eksperimen yang dibelajarkan dengan model pembelajaran PAKEM berbasis Tri Kaya Parisudha diperoleh rata - rata post-test, $\bar{X}=85,094$ dengan standar deviasi 14,446 dan varians 208,675 sedangkan kompetensi pengetahuan PPKn pada kelompok kontrol yang dibelajarkan melalui pembelajaran konvensional diperoleh rata - rata post-test $\bar{X}=74,782$ dengan standar deviasi 14,159 dan varians 200,479.

Tabel 1. Rekapitulasi Data Post-test Kompetensi Pengetahuan PPKn Kelompok Eksperimen dan Kelompok Kontrol

\begin{tabular}{lcc}
\hline \multicolumn{1}{c}{ Data } & Kelompok Eksperimen & Kelompok Kontrol \\
\hline Mean & 85,094 & 74,782 \\
\hline Standar Deviasi & 14,446 & 14,159 \\
\hline Varians & 208,675 & 200,479 \\
\hline Nilai Terendah & 41 & 33 \\
\hline Nilai Tertinggi & 97 & 92 \\
\hline
\end{tabular}

Dari hasil data perhitungan yang diperoleh pada tabel 01., menunjukkan bahwa post-test kompetensi pengetahuan PPKn siswa kelompok eksperimen yang mengikuti pembelajaran menggunakan model pembelajaran PAKEM berbasis Tri Kaya Parisudha memiliki nilai rata - rata yang lebih tinggi daripada kelompok kontrol yang mengikuti pembelajaran menggunakan pembelajaran konvensional.

Uji normalitas sebaran data yang dilakukan menggunakan uji Kolmogorov-Smirnov. Uji ini dilakukan pada kedua kelompok data yang meliputi data kelompok siswa yang dibelajarkan melalui model pembelajaran PAKEM berbasis Tri Kaya Parisudha dan data kelompok yang dibelajarkan melalui pembelajaran konvensional. Berdasarkan perhitungan hasil uji normalitas sebaran data post-test kompetensi pengetahuan PPKn siswa di kelompok eksperimen, diperoleh nilai maksimum $\left|\mathrm{F}_{\mathrm{T}}-\mathrm{F}_{s}\right|=$ 0,213 sedangkan untuk nilai tabel Kolmogorov-Smirnov $(\alpha=0,05)=0,227$ karena nilai maksimum 
$\left|\mathrm{F}_{\mathrm{T}}-\mathrm{F}_{S}\right|=0,213 \leq$ nilai tabel Kolmogorov-Smirnov $(\alpha=0,05)=0,227$ maka sebaran data post-test pada kelompok eksperimen berdistribusi normal.

Perhitungan hasil uji normalitas sebaran data post-test siswa di kelompok kontrol, diperoleh nilai maksimum $\left|\mathrm{F}_{\mathrm{T}}-\mathrm{F}_{S}\right|=0,151$ sedangkan untuk nilai tabel Kolmogorov-Smirnov $(\alpha=0,05)=0,215$ karena nilai maksimum $\left|\mathrm{F}_{\mathrm{T}}-\mathrm{F}_{S}\right|=0,151 \leq$ nilai tabel Kolmogorov-Smirnov $(\alpha=0,05)=0,215$ maka sebaran data post-test pada kelompok kontrol berdistribusi normal.

Setelah data berdistribusi normal, selanjutnya dilakukan uji homogenitas varians. Pengujian homogenitas varians antar kelompok - kelompok dimaksudkan untuk meyakinkan bahwa perbedaan yang diperoleh uji-t benar - benar berasal dari perbedaan antar kelompok bukan disebabkan oleh perbedaan di dalam kelompok. Uji homogenitas varians dilakukan terhadap data kompetensi pengetahuan PPKn antara kelompok eksperimen dan kelompok kontrol. Uji homogenitas varians yang dilakukan dalam penelitian ini menggunakan uji $\mathrm{F}$ (uji fisher). Pengujian homogenitas varians menggunakan uji F pada taraf signifikansi $5 \%(\alpha=0,05)$. Diperoleh $\mathrm{F}_{\text {hitung }}=1,04$ sedangkan untuk taraf signifikansi $5 \% \mathrm{~F}_{\text {tabel }}$ dengan $\mathrm{dk}(33,37)$ adalah 1,78. Ini berarti $\mathrm{F}_{\text {hitung }} \leq \mathrm{F}_{\text {tabel }}, 1,04 \leq 1,78$ sehingga data kompetensi pengetahuan PPKn antara kelompok eksperimen dan kelompok kontrol mempunyai varians yang homogen.

Berdasarkan hasil uji prasyarat yang terdiri dari uji normalitas sebaran data dan uji homogenitas varians diperoleh data pada kedua kelompok yaitu siswa yang dibelajarkan dengan model pembelajaran PAKEM berbasis Tri Kaya Parisudha dan siswa yang dibelajarkan melalui pembelajaran konvensional berdistribusi normal dan memiliki varians yang homogen, selanjutnya dilakukan uji hipotesis. Berdasarkan hal ini maka uji hipotesis menggunakan analisis uji-t dengan rumus polled varians.

Adapun kriteria pengujiannya adalah apabila $t_{\text {hitung }} \leq t_{\text {tabel }}$, maka Ho diterima dan Ha ditolak. Sebaliknya apabila $t_{\text {hitung }}>t_{\text {tabel }}$, maka Ho ditolak dan Ha diterima. Dengan $d k=n_{1}+n_{2}-2$ dan taraf signifikansi 5\% $(\alpha=0,05)$. Berdasarkan hasil analisis uji-t dari kompetensi pengetahuan PPKn siswa diperoleh hasil sebagai berikut.

Tabel 2. Rekapitulasi Hasil Analisis Uji-t Kelompok Sampel Penelitian

\begin{tabular}{|c|c|c|c|c|c|c|c|c|}
\hline No. & $\begin{array}{c}\text { Kelompok } \\
\text { Sampel }\end{array}$ & $\mathbf{N}$ & $\mathbf{d k}$ & $\begin{array}{l}\text { Rata-rata } \\
\text { Post-test }\end{array}$ & $S^{2}$ & $\mathbf{t}_{\text {hitung }}$ & $t_{\text {tabel }}$ & Keterangan \\
\hline 1 & Eksperimen & 34 & \multirow{2}{*}{70} & 85,094 & 208,675 & \multirow{2}{*}{3,048} & \multirow{2}{*}{2,000} & \multirow{2}{*}{ Ho ditolak } \\
\hline 2 & Kontrol & 38 & & 74,782 & 200,479 & & & \\
\hline
\end{tabular}

Berdasarkan tabel 02., menunjukkan bahwa hasil analisis uji-t diperoleh $t_{\text {hitung }}=3,048$ harga tersebut kemudian dibandingkan dengan harga $t_{\text {tabel }}$ dengan $\mathrm{dk}=34+38-2=70$ dan taraf signifikansi $5 \%(\alpha=0,05)$ sehingga diperoleh harga $t_{\text {tabel }}=2,000$ karena $t_{\text {hitung }}>t_{\text {tabel, }} t_{\text {hitung }}=3,048>t_{\text {tabel }}(\alpha=0,05)$ $=2,000$ maka Ho ditolak. Hal ini berarti terdapat perbedaan yang signifikan kompetensi pengetahuan PPKn siswa yang dibelajarkan menggunakan model pembelajaran PAKEM berbasis Tri Kaya Parisudha dan siswa yang dibelajarkan menggunakan pembelajaran konvensional pada siswa kelas IV SDN Gugus Patimura Denpasar Selatan Tahun Ajaran 2019/2020. Nilai rata-rata post-test yang diperoleh pada kelompok eksperimen yang dibelajarkan menggunakan model pembelajaran PAKEM berbasis Tri Kaya Parisudha adalah $\bar{X}=85,094$ sedangkan nilai rata-rata post-test yang diperoleh pada kelompok kontrol yang dibelajarkan menggunakan pembelajaran konvensional adalah $\bar{X}=74,782$. Sehingga nilai rata rata post-test kompetensi pengetahuan PPKn siswa kelompok eksperimen 85,094 lebih besar dari 74,782 yaitu nilai rata-rata post-test kompetensi pengetahuan PPKn siswa kelompok kontrol. Jadi dapat disimpulkan bahwa terdapat pengaruh yang signifikan model pembelajaran PAKEM berbasis Tri Kaya Parisudha terhadap kompetensi pengetahuan PPKn siswa kelas IV SDN Gugus Patimura Denpasar Selatan Tahun Ajaran 2019/2020.

Perolehan hasil perhitungan yang menunjukkan nilai rata-rata post-test kompetensi pengetahuan PPKn siswa kelas IV A SD Negeri 11 Sesetan pada kelompok eksperimen yaitu 85,094 dan nilai rata-rata post-test kompetensi pengetahuan PPKn siswa kelas IV SD Negeri 7 Sesetan pada kelompok kontrol yaitu 74,782. Dilihat dari nilai rata-rata post-test yang diperoleh, bahwa siswa pada kelompok eksperimen memiliki nilai rata-rata lebih tinggi daripada siswa pada kelompok kontrol. Hal ini berarti kelompok yang diberikan perlakuan dengan menggunakan model pembelajaran PAKEM berbasis Tri Kaya Parisudha berpengaruh terhadap kompetensi pengetahuan PPKn siswa kelas IV SDN 
Gugus Patimura Denpasar Selatan Tahun Ajaran 2019/2020. Dengan demikian, model pembelajaran PAKEM berbasis Tri Kaya Parisudha dapat direkomendasikan dalam pembelajaran siswa khususnya pada kegiatan pembelajaran yang berisi muatan materi PPKn selain model pembelajaran konvensional.

Berdasarkan perolehan kompetensi pengetahuan PPKn pada kedua kelompok dapat diketahui bahwa kedua kelompok yang awalnya memiliki kemampuan yang setara, setelah diberikan perlakuan pada kelompok eksperimen dengan model pembelajaran PAKEM berbasis Tri Kaya Parisudha maka perolehan nilai kompetensi pengetahuan PPKn mengalami peningkatan. Kompetensi pengetahuan PPKn siswa pada kelompok eksperimen lebih baik apabila dibandingkan dengan kompetensi pengetahuan PPKn siswa pada kelompok kontrol. Hal ini disebabkan oleh pembelajaran yang diterapkan pada kelompok eksperimen memiliki banyak kelebihan serta pembelajaran pada kelompok eksperimen yang menerapkan model pembelajaran PAKEM berbasis Tri Kaya Parisudha dapat membangkitkan keaktifan siswa dalam mengikuti pembelajaran, karena dengan diterapkan model pembelajaran PAKEM berbasis Tri Kaya Parisudha dapat berpikir kreatif dan inovatif dalam memahami pembelajaran sehingga pembelajaran akan menjadi lebih bermakna dan menyenangkan. Model pembelajaran PAKEM berbasis Tri Kaya Parisudha juga dapat meningkatkan suasana belajar dan dapat meningkatkan kemampuan siswa dalam memecahkan masalah sehingga dapat melatih kemampuan berpikir kritis siswa.

PAKEM merupakan model pembelajaran dan menjadi pedoman dalam bertindak untuk mencapai tujuan yang telah ditetapkan (Rusman, 2016). Dengan pelaksanaan pembelajaran PAKEM, diharapkan berkembangnya berbagai macam inovasi kegiatan pembelajaran untuk mencapai tujuan pembelajaran yang partisipatif, aktif, efektif dan menyenangkan. Menerapkan model pembelajaran PAKEM berbasis Tri Kaya Parisudha memudahkan siswa untuk mengingat informasi serta mengeluarkan gagasan, ide dan pikiran siswa dalam menanggapi suatu permasalahan pada pembelajaran. Adapun kelebihan dari model pembelajaran PAKEM berbasis Tri Kaya Parisudha menurut (Iru \& Arihi, 2012:80) yaitu : (1) PAKEM merupakan pembelajaran yang mengembangkan kecakapan hidup, (2) Dalam PAKEM siswa belajar menghasilkan karya kreatif, (3) PAKEM mendorong siswa menghasilkan karya kreatif, (4) PAKEM mendorong siswa untuk terus maju mencapai sukses, (5) PAKEM menghargai potensi semua siswa, (6) Program untuk meningkatkan PAKEM di sekolah harus ditingkatkan kuantitas dan kualitasnya.

Hasil temuan pada penelitian ini memiliki persamaan dengan penelitian sebelumnya yang relevan dan memperkuat hasil penelitian yang diperoleh. Penelitian ini sesuai dengan penelitian Pradnyawathi \& Agustika (2019) yang melakukan penelitian mengenai pengaruh model pembelajaran PAKEM berbasis Tri Hita Karana terhadap keterampilan menulis. Hasil analisis yang menunjukkan bahwa terdapat perbedaan yang signifikan keterampilan menulis kelompok siswa yang dibelajarkan menggunakan model PAKEM berbasis Tri Hita Karana dengan kelompok siswa yang dibelajarkan melalui pembelajaran konvensional. Dengan analisis menunjukkan hasil $t_{\text {hitung }}=4,278>t_{\text {tabel }}(\alpha=0,05,79)=$ 1,990 artinya model pembelajaran PAKEM berbasis Tri Hita Karana berpengaruh secara signifikan terhadap keterampilan menulis siswa kelas IV SD Gugus Letkol Wisnu Denpasar Utara Tahun Ajaran 2017/2018. Penelitian ini juga didukung oleh penelitian yang dilakukan (Sucini et al., 2019) yang melakukan penelitian mengenai model pembelajaran Word Square berbasis Tri Kaya Parisudha terhadap hasil belajar PKn. Hasil perhitungan analisis data menunjukkan $t_{\text {hitung }}=28,02$ dan $t_{\text {tab }}=2,021$, sehingga $t_{\text {hitung }}$ lebih besar dari $t_{\text {tab }}(28,02>2,021)$ sehingga penelitiannya menunjukkan bahwa terdapat pengaruh model pembelajaran word square berbasis Tri Kaya Parisudha terhadap hasil belajar PKn pada siswa kelas V SD di Gugus XIV Kecamatan Buleleng Tahun Ajaran 2018/2019.

Selain itu, juga didukung juga penelitian dilakukan oleh (Arsani et al., 2013) dengan hasil analisis menunjukkan bahwa terdapat perbedaan hasil belajar Pendidikan Kewarganegaraan yang signifikan antara kelompok siswa yang dibelajarkan metode pembelajaran bermain peran berorientasi kearifan lokal Tri Kaya Parisudha dengan kelompok siswa yang dibelajarkan metode pembelajaran diskusi ( $\mathrm{t}_{\text {hitung }}$ $=3,415>t_{\text {tabel }}=2,000$ ). Dengan demikian metode pembelajaran bermain peran berorientasi kearifan lokal Tri Kaya Parisudha terhadap hasil belajar Pendidikan Kewarganegaraan. (N. W. T. S. Dewi et al., 2019) menyimpulkan bahwa terdapat pengaruh model pembelajaran Value Clarification Technique (VCT) berbasis tri kaya parisudha terhadap Sikap Sosial Siswa Pada Mata Pelajaran PKn Kelas V. Dan penelitian oleh (Suarnaya et al., 2015) yang melakukan penelitian mengenai pengaruh model pembelajaran tandur berbasis kearifan lokal tri kaya parisudha terhadap hasil belajar IPA. Hasil penelitiannya menunjukkan bahwa terdapat perbedaan yang signifikan hasil belajar IPA antara 
kelompok yang mengikuti pembelajaran dengan model pembelajaran tandur berbasis kearifan lokal Tri Kaya Parisudha dan Kelompok yang mengikuti pembelajaran dengan model pembelajaran konvensional. Dilihat dari hasil perhitungan $\mathrm{t}$ hitung $=5,94>\mathrm{t}$ tabel $=2,000$ dengan taraf signifikansi $5 \%$, sehingga dapat diinterpretasikan bahwa terdapat perbedaan hasil belajar IPA yang signifikan. Dengan demikian dapat disimpulkan bahwa model pembelajaran tandur berbasis Tri Kaya Parisudha berpengaruh terhadap hasil belajar IPA. Dan penelitian yang dilakukan oleh (Defa et al., 2017) berpengaruhnya penerapan model pembelajaran Wayang Sejarah karena dapat meningkatkan keaktipan dan pemahaman siswa pada Pelajaran IPS.

Pada penerapan model pembelajaran PAKEM berbasis Tri Kaya Parisudha pada kelompok eksperimen menjadikan siswa dilatih untuk mengembangkan keterampilan berpikir siswa untuk mengerjakan kegiatan yang beragam dalam mengembangkan sikap, keterampilan, dan pemahaman siswa terhadap berbagai sumber belajar agar pembelajaran berlangsung dengan menyenangkan, menarik dan efektif. Hal ini dapat menyebabkan siswa lebih berani mengungkapkan pendapatnya, sehingga siswa lebih berpartisipasi dalam kegiatan belajar. Model pembelajaran PAKEM berbasis Tri Kaya Parisudha dapat memudahkan siswa untuk menyampaikan informasi yang menggambarkan kegiatan pembelajaran yang menyenangkan. Kegiatan pembelajaran yang dilakukan oleh guru dengan menggunakan model pembelajaran PAKEM berbasis Tri Kaya Parisudha dapat memusatkan perhatiannya untuk memberikan suatu pendapatnya terhadap masalah yang diberikan oleh guru, dan melatih siswa untuk mengembangkan daya berpikir, kreativitas, dan keberanian untuk mengungkapkan pendapatnya. Dengan demikian pembelajaran yang bersifat menyenangkan memberikan siswa perasaaan yang termotivasi untuk belajar dengan sendiri.

Dari hasil penelitian telah dilakukan diketahui bahwa potensi yang ada pada penelitian ini dapat dikembangkan lebih lanjut untuk memperoleh hasil yang lebih baik serta menggambarkan keadaan sesungguhnya yang terjadi di lapangan. Pada implikasi penelitian ini mencangkup dua hal yaitu implikasi teoretis dan implikasi praktis adapun penjelasannya yaitu sebagai berikut. Pada implikasi teoretis pada penelitian ini ialah pemilihan model pembelajaran yang tepat akan memengaruhi kemampuan siswa untuk mempelajari kompetensi pengetahuan PPKn. Penelitian ini membuktikan bahwa model pembelajaran PAKEM berbasis Tri Kaya Parisudha dapat diterapkan dengan baik dalam proses pembelajaran untuk mengoptimalkan kemampuan siswa dalam kompetensi pengetahuan PPKn. Menerapkan model pembelajaran PAKEM berbasis Tri Kaya Parisudha dapat membuat siswa lebih aktif dan pembelajaran lebih bermakna. Dalam pemberian pembelajaran guru maupun pihak sekolah harus mempersiapkan sarana dan prasarana yang diperlukan seperti buku siswa dan buku guru serta buku penunjang lainnya yang berkaitan dengan muatan materi PPKn.

Implikasi praktis pada penelitian ini ialah model pembelajaran PAKEM berbasis Tri Kaya Parisudha digunakan sebagai bahan masukan bagi guru karena model pembelajaran PAKEM berbasis Tri Kaya Parisudha memberikan pembelajaran yang bermakna serta siswa dapat mengaitkan ajaran - ajaran agama dengan kegiatan pembelajaran yang menyenangkan. Selain itu meningkatkan sikap optimis dan memotivasi siswa dalam mengikuti pembelajaran. Hasil penelitian ini dapat digeneralisasikan pada populasi penelitian. Hal ini menunjukkan bahwa model pembelajaran PAKEM berbasis Tri Kaya Parisudha dapat diterapkan di seluruh SDN Gugus Patimura Denpasar Selatan.

\section{SIMPULAN DAN SARAN}

Berdasarkan hasil penelitian dan pembahasan yang telah dipaparkan diperoleh hasil uji hipotesis dengan menggunakan uji-t maka diperoleh $t_{\text {hitung }}$ lebih besar daripada $t_{\text {tabel, }}$ maka $\mathrm{H}_{\mathrm{o}}$ ditolak dan $\mathrm{H}_{\mathrm{a}}$ diterima. Hal ini berarti terdapat perbedaan yang signifikan kompetensi pengetahuan PPKn siswa yang dibelajarkan menggunakan model pembelajaran PAKEM berbasis Tri Kaya Parisudha dan siswa yang dibelajarkan menggunakan pembelajaran konvensional pada siswa kelas IV SDN Gugus Patimura Denpasar Selatan Tahun Ajaran 2019/2020. Nilai rata - rata post-test kompetensi pengetahuan PPKn siswa kelompok eksperimen memiliki nilai yang lebih tinggi dibandingkan nilai rata - rata post-test kompetensi pengetahuan PPKn siswa kelompok kontrol. Jadi dapat disimpulkan bahwa terdapat pengaruh yang signifikan model pembelajaran PAKEM berbasis Tri Kaya Parisudha terhadap kompetensi pengetahuan PPKn siswa kelas IV SDN Gugus Patimura Denpasar Selatan Tahun Ajaran 2019/2020. Berdasarkan simpulan dari penelitian ini, adapun saran yang dapat disampaikan kepada pihak-pihak sebagai berikut yaitu pertama ditunjukkan kepada guru disarankan lebih kreatif dan terampil dalam memberikan variasi model pada proses kegiatan pembelajaran. Dari hasil kompetensi 
pengetahuan pada muatan materi PPKn menggunakan model pembelajaran PAKEM berbasis Tri Kaya Parisudha, hendaknya guru dapat menerapkan model pembelajaran ini khususnya pada muatan materi PPKn. Kedua ditunjukkan kepada peneliti lain diharapkan supaya hasil ini digunakan sebagai referensi untuk melakukan penelitian selanjutnya pada pokok bahasan yang berbeda dan pada sampel yang berbeda untuk memperoleh hasil yang lebih baik dan dapat menggambarkan keadaan sesungguhnya yang terjadi di lapangan. Terakhir ditunjukkan kepada lembaga pendidikan diharapkan menyediakan sarana yang maksimal demi menunjang proses pembelajaran supaya siswa dapat memanfaatkan sarana tersebut untuk mengoptimalkan kompetensi pengetahuan siswa sehingga mutu sekolah semakin meningkat.

\section{DAFTAR PUSTAKA}

Anwar, M. (2015). Filsafat Pendidikan (Jakarta). Kencana.

Arsani, N. N. S., Murda, I. N., \& Wirya, I. N. (2013). Pengaruh Metode Pembelajaran Bermain Peran Berorientasi Kearifan Lokal Tri Kaya Parisudha Terhadap Hasil Belajar Pendidikan Kewarganegaraan Siswa Kelas V SD. Mimbar PGSD, 1(1), 1-10. https://ejournal.undiksha.ac.id/index.php/JJPG/article /view /880/751

Ary W, P. P., Ganing, N. N., \& Suardika, I. W. R. (2014). Pembelajaran Pakem Berbantuan Permainan Pesan Berantai Berpengaruh Terhadap Hasil Belajar Bahasa Indonesia. MIMBAR PGSD Undiksha, 2(1). https://doi.org/10.23887/jjpgsd.v2i1.2553

Darmadi, H. (2014). Urgensi Pendidikan Pancasila dan Kewarganegaraan di Perguruan Tinggi. Alfabeta.

Defa, Desrini, F., \& Tarigan, F. (2017). Pengaruh Metode PAKEM Terhadap Hasil Belajar Siswa Pada Mata Pelajaran IPS Materi Kerajaan-Kerajaan Hindu di Indonesia Dengan Membuat Alat Peraga Wayang Sejarah di Kelas $V$ SDN 116874 Bakaran Batu Kabupaten Labuhanbatu. https://jurnal.unimed.ac.id/2012/index.php/snpu/article/view/15016/0

Dewi, A. . I. R. M., Murda, I. N., \& Tegeh, I. M. (2014). Pengaruh Model Vct Berlandaskan Konsep Tri Kaya Siswa Kelas V di SD Gugus III Kecamatan Seririt 2013 / 2014. Jurnal Mimbar PGSD Universitas Pendidikan Ganesha, https://ejournal.undiksha.ac.id/index.php/JJPGSD/article/view/2430

Dewi, N. W. T. S., Wibawa, I. M. C., \& Agustina, I. G. A. T. (2019). Pengaruh Model Pembelajaran Value Clarification Technique Berbasis Tri Kaya Parisudha Terhadap Sikap Sosial Siswa Pada Mata Pelajaran Pkn Kelas V. Media Komunikasi FPIPS, 18(1), 11-21. https://doi.org/10.23887/mkfis.v18i1.22234

Ernawati, L. P. N. (2018). Penerapan Ajaran Tri Kaya Parisudha Dalam Pembentukan Perilaku yang Baik Terhadap Peserta Didik. Cetta: Jurnal Ilmu Pendidikan, 1(1), 26-32. http://ejournal.jayapanguspress.org/index.php/cetta

Ginting, I. N. B. (2017). Penerapan Pendekatan PAKEM Untuk Meningkatkan Minar dan Hasil Belajar Pendidikan Kewarganegaraan. 254-258. http://digilib.unimed.ac.id/28157/

Indrawati, \& S., W. (2009). Pembelajaran Aktif, Kreatif, Efektif, dan Menyenangkan Untuk Guru SD. PPPPTK IPA.

Indrayani, P. S., Arini, N. W., \& Rati, N. W. (2018). Pengaruh Model Pembelajaran Kooperatif Tipe TTW Terhadap Hasil Belajar IPA Pada Siswa Kelas V SD. Jurnal Mimbar PGSD, 2(1).

Iru, L. \& L. O. S. A. (2012). Analisis Penerapan Pendekatan, Metode, Strategi, dan Model - Model Pembelajaran. Multi Presindo.

Krisnawati, M., Arini, N. W., \& Suarjana, M. (2013). Penerapan Pendekatan (PAKEM) Untuk Meningkatkan Aktivitas dan Hasil Belajar Bahasa Indonesia SIswa Kelas IV SD No. 2 Pemaron. MIMBAR PGSD Undiksha, https://ejournal.undiksha.ac.id/index.php/JJPGSD/article/view/1481

Kurniasih, Imas. \& Berlin, S. (2014). Sukses Mengimplementasikan Kurikulum 2013 Memahami Berbagai Aspek Dalam Kurikulum 2013. Kata Pena.

Nurhayati. (2016). Peningkatan Partisipasi dan Prestasi Belajar PKn Dengan Model PAKEM Siswa Sekolah Dasar. JPSD: Jurnal Pendidikan Sekolah Dasa, 2(1), 43-51.

Pradnyawathi, N. N. C., \& Agustika, G. N. S. (2019). Pengaruh Model Pakem Berbasis Tri Hita Karana terhadap Keterampilan Menulis. International Journal of Elementary Education, 3(1), 89-98. https://ejournal.undiksha.ac.id/index.php/IJEE/article/view/17660

Rithayanti, N. W. N., Wiyasa, I. K. N., \& Asri, I. G. A. A. S. (2014). Pengaruh Pendekatan Pembelajaran Aktif 
Kreatif Efektif dan Menyenangkan (PAKEM) Berbantuan Media Grafis terhadap Hasil Belajar IPS Siswa Kelas V SD Gugus Srikandi Denpasar. Jurnal Mimbar PGSD Universitas Pendidikan Ganesha, 2(1). https://ejournal.undiksha.ac.id/index.php/JJPGSD/article/view/2206

Rusman. (2016). Model - Model Pembelajaran: Mengembangkan Profesionalisme Guru. Rajawali Pers.

Sariani, N. L. A., Suarjana, I. M., \& Dibia, I. K. (2018). Pengaruh Model Pembelajaran CTL Berorientasi Matematika Siswa Kelas III. International Journal of Elementary Education, 2, 95-102. https://ejournal.undiksha.ac.id/index.php/IJEE/article/view/15963

Setyosari, P. (2015). Metode Penelitian Pendidikan dan Pengembangan. Kencana.

Suarnaya, K. D., Dibia, I. K., \& Suarjana, M. (2015). Pengaruh Model Pembelajaran TANDUR Berbasis Kearifan Lokal Tri Kaya Parisudha Terhadap Hasil Belajar IPA. E-Journal PGSD Universitas Pendidikan Ganesha, 3(1). https://ejournal.undiksha.ac.id/index.php/ JJPGSD/article/view/4815

Sucini, I. M. A., Suwatra, I. W. I., \& Suarjana, I. M. (2019). Pengaruh Model Pembelajaran Word Square Berbasis Tri Kaya Parisudha Terhadap Hasil Belajar PKn. Jurnal Ilmiah Sekolah Dasar, 3(4), 448457. https://doi.org/10.31539/spej.v2i2.726

Sugiyono. (2017a). Metode Penelitian Pendidikan (Pendekatan Kuantitatif, Kualitatif dan R\&D). Alfabeta. Sugiyono. (2017b). Statistika untuk Penelitian. Alfabeta.

Suhardana, M. (2007). Tri Kaya Parisudha. Paramitha.

Suharsimi, A. (2016). Dasar - Dasar Evaluasi Pendidikan. Bumi Aksara.

Sulastri, E. (2019). 9 Aplikasi Metode Pembelajaran. Guepedia.

Suparman. (2016). Pengaruh Pembelajaran PAKEM dalam Meningkatkan Prestasi Belajar Pendidikan Kewarganegaraan Pada Siswa Kelas VI SDN Glanggang I Tahun Pelajaran 2015/2026. Jurnal Ilmiah Edukasi \& Sosial, 7(2), 115-121. http://jiesjournal.com/index.php/jies/article/view/64

Undang - Undang Republik Indonesia Nomor 20 Tahun 2003 Tentang Sistem Pendidikan Nasional. (2003). Pemerintah Republik Indonesia.

Widiasih, L. S., Suarjana, I. M., \& Tanggu, R. N. (2019). Pengaruh Model Pembelajaran SFAE Berbasis Tri Kaya Parisudha Terhadap Hasil Belajar Matematika Siswa. Jurnal Ilmiah Sekolah Dasar, 3(2), 135141. https://doi.org/http://dx.doi.org/10.23887/jisd.v3i2.17758 